\title{
The large roman water mill at Barbegal (France)
}

\section{Le grand moulin à eau romain de Barbegal}

Robert H. J. Sellin*

Department of Civil Engineering

University of Bristol U. K.

\section{Introduction}

A few kilometres from Arles in the south of France it is possible to see the impressive remains of a GalloRoman corn mill at Barbegal (Fig. 1), that was probably powered by 16 over-shot water wheels. These were

\section{Introduction}

A Barbegal, situé à quelques kilomètres d'Arles dans le sud de la France, on peut découvrir les impressionnants vestiges d'un moulin à grain gallo-romain (voir Fig. 1) qui fonctionnait probablement à l'aide de

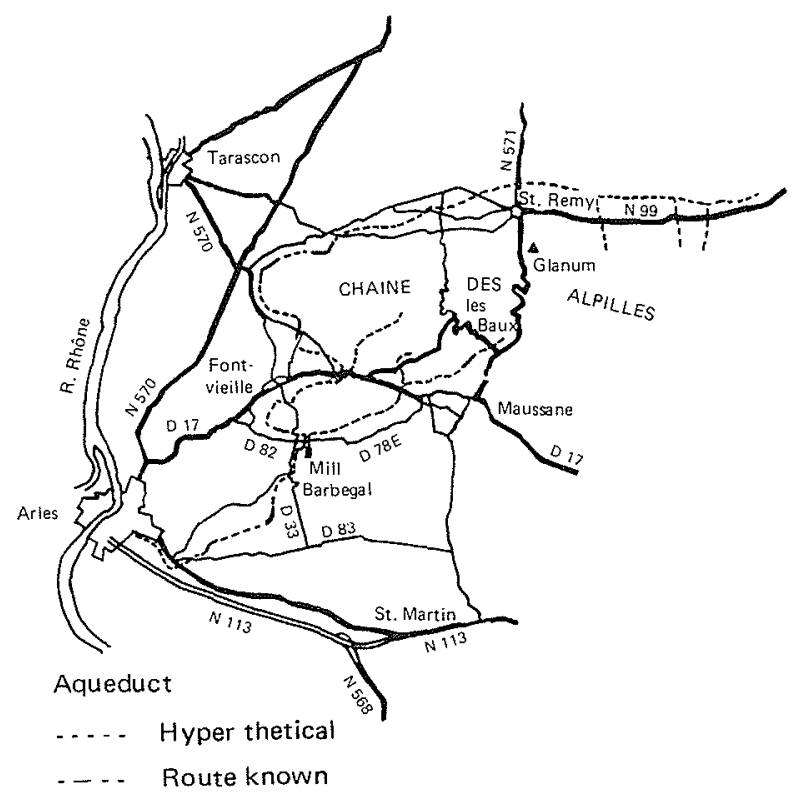

Figure 1 - Location map showing Barbegal mill and Arles aqueduct. Figure 1 - Carte localisant le moulin de Barbegal et l'aqueduc d'Arles.

arranged in two parallel cascades running down either side of a single large building constructed on the slope of a hill. In attempting to assess the significance of this remarkable complex it must be remembered that there is clear archaeological evidence of earlier but much smaller water mills in the Greco-Roman world and
16 roues mises en mouvement par des chutes d'eau. Celles-ci étaient disposées en cascades parallèles de chaque côté d'un seul grand bâtiment construit sur le flanc d'une colline. Pour essayer de comprendre la signification de cet ensemble remarquable, il faut se rappeler qu'il existe des témoignages archéologiques

LA HOUILLE BLANCHE / No 6-1981 
evidence also that water driven corn mills remained in use in various parts of the former Roman Empire after that ceased to exist and probably through to the middle ages where their construction and use becomes much more in evidence again. Barbegal has proved rather difficult to date with confidence but it is now thought to have been built in the 4th century AD despite its style of construction which appears to imitate a neighbouring 1st century aquaduct. Although Barbegal today is neither so complete nor so large as the better known Pont-du-Gard some $60 \mathrm{~km}$ to the West it is probable that it was the first large industrial unit (factory) not powered by slaves or animals and that it was not surpassed in size or power consumption, in Europe at least, for many centuries afterwards. What is still clear today is that it was planned and constructed as a single unit, the site was chosen with great care and skill, the water to drive it was brought up to $9 \mathrm{~km}$ in a specially constructed single-purpose aqueduct and that it could have had a flour output sufficient to feed a large part of the Gallo-Roman population of Arles at that time.

The mill structure, shown in Figure 2, is built on a short steep hillside which faces south at a slope of $30^{\circ}$. Its ground plan, based on the original reconstruction first published by F. Benoit [1], is shown in Figure 3 . It has been constructed on a rocky surface now almost bare of vegetation and topsoil and does not coincide with any natural drainage course. The engineer responsible for its construction chose this site because it gave a concentrated fall ( $20 \mathrm{~m}$ in $60 \mathrm{~m}$ horizontal distance) yet lies in an open position in which the construction of a large masonry building $(50 \times 20 \mathrm{~m})$ would not prove too difficult. The site is also one to which easy access is available at the bottom by a road constructed along the foot of the slope, and with reasonable access at the top for the aqueduct carrying the water.

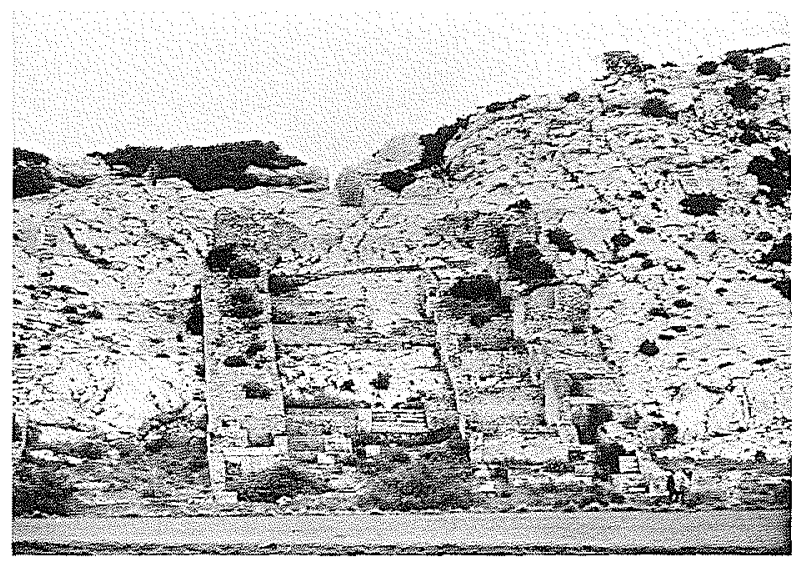

Figure 2 - The site of Barbegal seen from the South. Figure 2 - Le site de Barbegal vu du sud. certains dans le monde gallo-romain, de moulins à eau antérieurs mais plus petits; il est prouvé également que des moulins à eau pour la mouture du grain étaient toujours en usage dans l'ancien Empire Romain après que celui-ci eut cessé d'exister et probablement jusqu'au Moyen-Age où l'on trouve à nouveau des témoignages plus évidents de leur construction et de leur utilisation. Il est plutôt difficile d'établir une date précise pour Barbegal, mais l'on pense que ce moulin a été construit au $4^{e}$ siècle de notre ère, malgré son style de construction qui semble imiter celui d'un aqueduc voisin, du $1^{\text {er }}$ siècle. Bien que le Barbegal d'aujourd'hui ne soit ni aussi complet ni aussi grand que le célèbre Pont-du-Gard, à quelques 60 kilomètres à l'ouest, il est probable que c'était, à l'époque, le premier grand ensemble industriel (usine) qui fonctionnait sans l'aide d'esclaves ou d'animaux et qui, pendant plusieurs siècles, demeura, en Europe tout au moins, le plus grand quant à la taille et à la consommation en énergie. Ce qui reste clair aujourd'hui c'est qu'il a été conçu et construit comme un seul ensemble, le site en a été choisi avec grand soin et habileté, un aqueduc a été spécialement construit dans le seul but d'y amener l'eau distante de $9 \mathrm{~km}$ et son débit en farine suffisait à nourrir une grande partie de la population gallo-romaine d'Arles à cette époque.

La structure représentée sur la figure 2 est construite sur le court mais abrupt versant d'une colline orientée vers le sud avec une pente de $30^{\circ}$. Son plan horizontal, basé sur la construction originale édité pour la première fois par $F$. Benoit [1], est représenté par la figure 3. Elle a été érigée sur une surface rocailleure, presque dénudée et dépourvue de sa couche supérieure à l'heure actuelle et à proximité de laquelle ne se trouve aucun réseau de drainage naturel. L'ingénieur responsable de sa construction a choisi ce site parce qu'il offrait une chute concentrée (20 $\mathrm{m}$ sur $60 \mathrm{~m}$ de distance horizontale) tout en se trouvant sur une étendue largement ouverte où la construction d'un grand édifice en maçonnerie $(50 \times 20 \mathrm{~m})$ ne présentait pas trop de problèmes. $L$ 'endroit est également facile d'accès, dans sa partie inférieure, grâce à une route construite le long du pied de la pente et d'accès pas trop difficile, dans sa partie supérieure, pour l'aqueduc amenant l'eau.

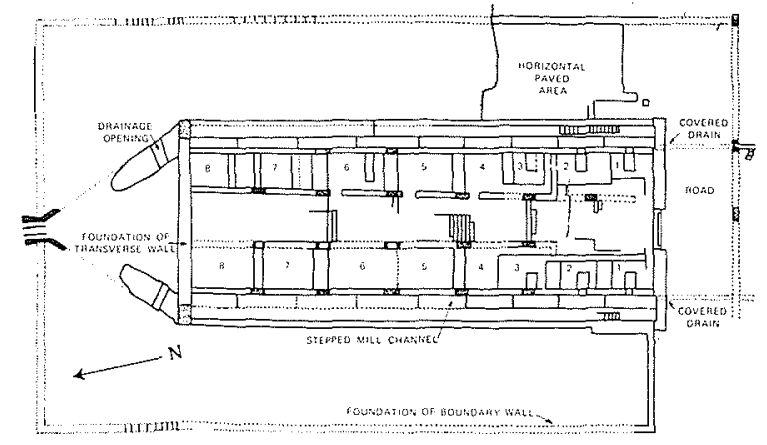

Figure 3 - Plan of mill at Barbegal (after Benoit). Figure 3 - Plan du moulin de Barbegal (d'après Benoit). 
The level ground at the foot of the slope was probably occupied by a marsh which is known to have been drained in the 17th century. There are signs that a channel contemporary with the mill was excavated across this marsh to carry the water from the mill in the direction of natural drainage. The mill was supplied with water at its upper level by an aqueduct thought to have followed a route where possible which allowed it to be constructed in a trench just below ground level but it was forced to cross a shallow valley elevated on a masonry structure for its last $400 \mathrm{~m}$ before it gained the low east-west ridge on the far side of which the mill was situated. Figure 4 shows a longitudinal profile and section through the site of the mill and the remains of the aqueduct adjacent to it. One of the most striking features of this site is the vertical sided cutting, Figure 5 and 6 , known locally as the "peiro troucado", excavated through the crest of the ridge to allow the aqueduct to
Le terrain plat au bas de la pente se composait, sans doute, d'un marécage asséché au $17^{e}$ siècle. D'après certains indices, un canal contemporain du moulin avait été creusé à travers ce marécage pour l'évacuation de l'eau du moulin vers le réseau de drainage naturel. Le moulin était alimenté en eau dans sa partie supérieure au moyen d'un aqueduc. On pense que cet aqueduc suivait une route dans la mesure du possible, ce qui permit sa construction dans une tranchée juste en-dessous $d u$ niveau du sol. Cependant, il dut être surélevé par une construction en maçonnerie pour traverser une petite vallee pour les derniers 400 mètres avant d'atteindre le côté le plus éloigné de la crête est-ouest où s'élevait le moulin. On voit sur la figure 4 un profil longitudinal et une section à travers le site du moulin et les vestiges de l'aqueduc attenant. L'une des caractéristiques les plus frappantes de ce site est la percée à rives verticales (Fig. 5 et 6) connue localement sour le nom de "peiro

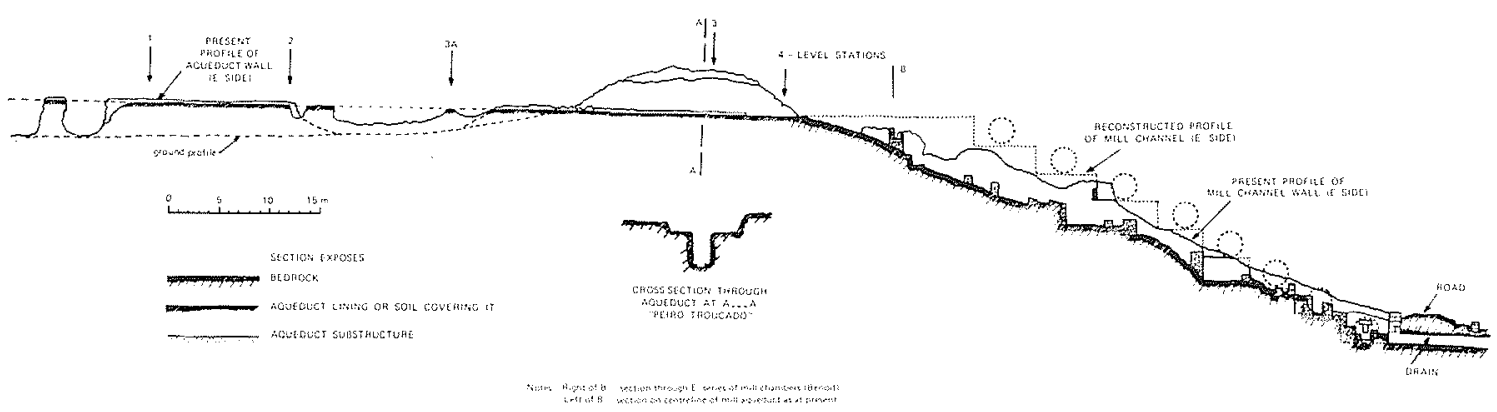

Figure 4 - Longitudinal profile and section through the mill.

Figure 4 - Profil longitudinal et section du moulin.
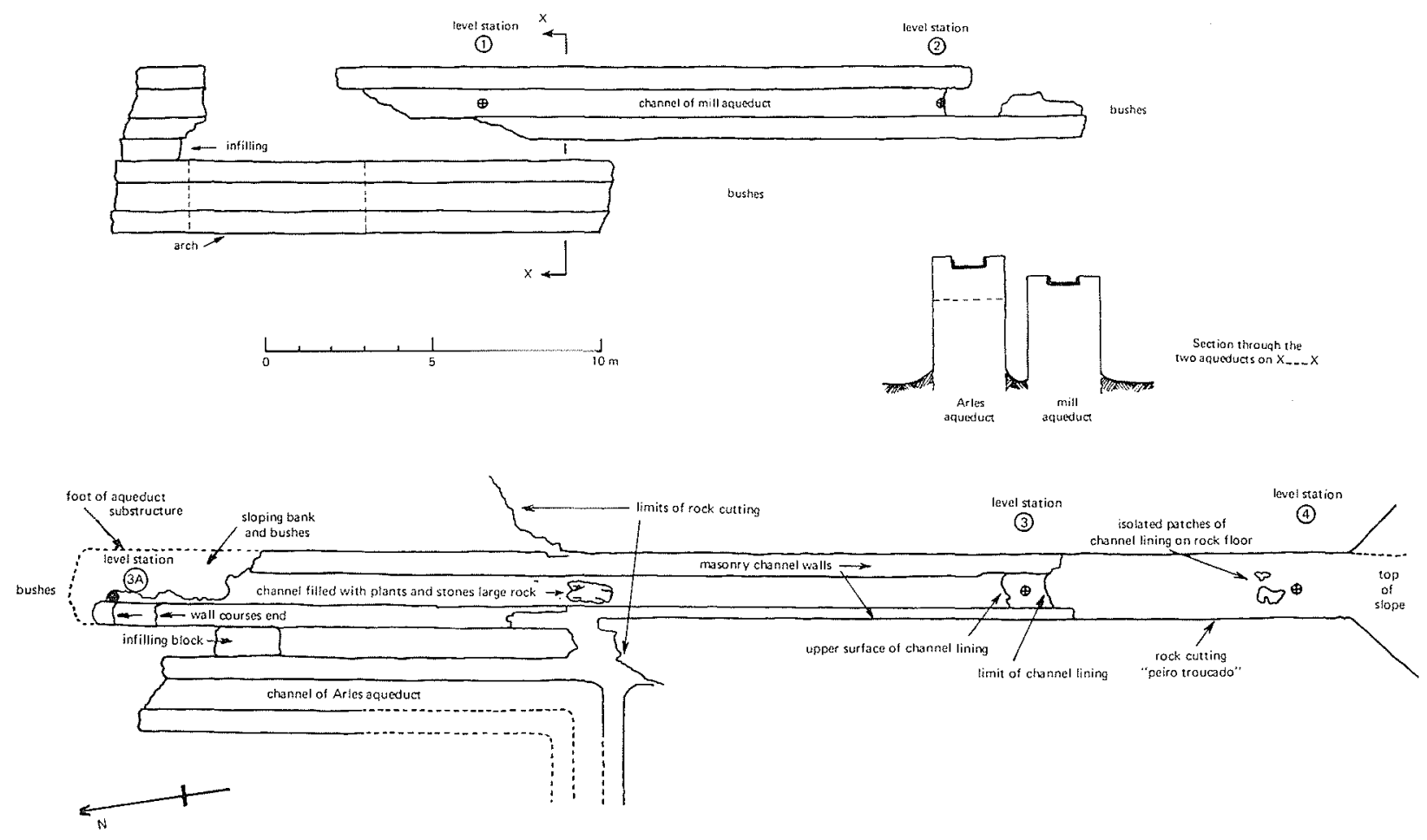

Figure 5 - Plan of the two aqueducts over a distance of $75 \mathrm{~m}$ North from the junction with the mill.

Figure 5 - Plan des deux aqueducs sur une distance de $75 \mathrm{~m}$ au nord de la jonction avec le moulin. 


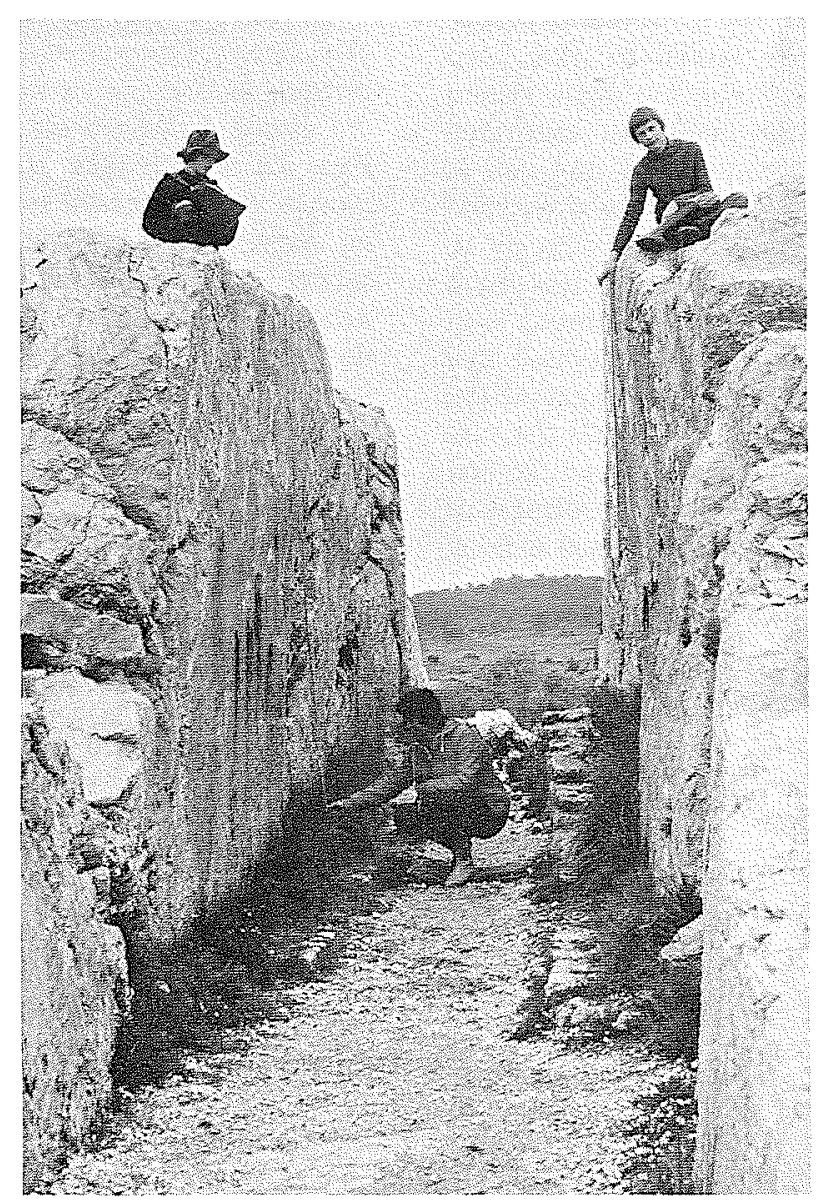

Figure 6 - View of South end of rock cutting "Peiro troucado" near aqueduct junction with mill.

Figure 6 - Vue de l'extrémité sud de la percée "Peiro troucado" près de la jonction de l'aqueduc et du moulin.

reach the South side so avoiding the need for a much higher and longer aqueduct arcade across the valley to the north.

Various estimates have been made of the probable output of flour from Barbegal on the basis of all the mills operating at the same time. This is discussed in greater detail in a later section but an upper value would now appear to be 9 tonnes per 24 hours which, if a 12 hour working day is assumed, gives 1640 tonnes per annum.

\section{Excavation and interpretation of the site}

Where the mill aqueduct crosses the valley above ground level, just before it reaches the ridge on which the mill is situated, a second aqueduct runs parallel and very close to it with the bed of its channel some $0.6 \mathrm{~m}$ above that of the one feeding the mill. This second aqueduct makes a sharp right-angle turn (Fig. 7) to the West on reaching the ridge, as shown in Figure 5, which it then skirts on its way to Arles which it once supplied with water.

A local historian, writing at the end of the 18th century, concluded that both these aqueducts had troucado", creusée à travers la crête pour permettre à l'aqueduc d'atteindre le côté sud, éliminant ainsi la nécessité d'une arcade plus haute et plus longue pour l'aqueduc pour traverser la vallée vers le nord.

Diverses estimations ont été faites quand au débit en farine foumi par le moulin de Barbegal en se basant sur tous les moulins en service à cette même époque. Ce sujet sera traité ultérieurement, mais il semble maintenant admis que la plus forte production était de 9 tonnes par jour. Pour une journée de 12 heures de travail, ceci donnerait 1640 tonnes l'an.

\section{Fouille et interprétation du site}

Là où l'aqueduc traverse la vallée avant son arrivée sur la crête où est situé le moulin, il se trouve en parallèle et très près d'un deuxième aqueduc, dont le lit du canal est à environ $0,60 \mathrm{~m}$ au-dessus de lui. Ce deuxième aqueduc fait un virage à angle droit (Fig. 7) vers l'ouest en atteignant la crête, comme indiqué sur la figure 5, puis il contourne la crête en poursuivant son chemin vers Arles qu'il alimentait jadis en eau.

Un historien local de la fin du $18^{e}$ siècle en a conclu que les deux aqueducs transportaient de l'eau pour la 


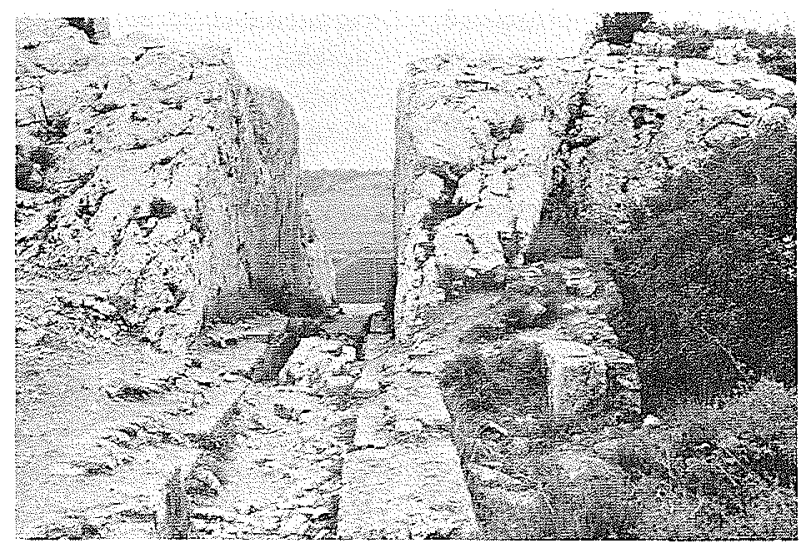

Figure 7 - View of North end of rock cutting. Right angle turn in Arles aqueduct is below bush at right hand side of photograph. Figure 7 - Vue de l'extrémité nord de la percée. Le virage à angle droit de l'aqueduc d'Arles se trouve sous le buisson, à droite de la photographie.

carried water to Arles and that the siructure on the southward facing slope of the ridge was the remains of a settling reservoir of a type fairly common in Roman water supply systems. Having noticed the difference in the bed levels of the two aqueducts he also concluded that the water from the lower one - which flowed through "the reservoir" - must have made its way independently to Arles on some structure now completely lost. A contemporary writer, who had examined the site more carefully, thought that it represented a reservoir divided into three major basins and a number of minor ones and thought that it had formed one of six Imperial cloth factories which were known to have been established. The same writer noted fragments of basalt mill wheel lying at the foot of the slope and concluded that these had served for grinding colouring pigment for cloth dying. Another local historian writing a little later recognised these millstones as of a type suitable for grinding corn and he therefore concluded that the site had had a double function - cloth finishing and corn grinding. A german archaeologist writing about the aqueducts of Nimes and Arles in 1910 accepted this double function theory but J. Formige writing in 1924 [2] took the view that the sites sole function had been flour milling.

A systematic excavation of the mill was planned in 1935 and carried out in 1937 and 1938 by F. Benoit. He published a full report [1] of his investigations in 1940 in which he concluded that this structure was definitely not a reservoir built on the side of a hill but a mill building designed to be powered by water wheels arranged in two parallel cascades down the slope, one on each side of the building. His ability to reconstruct a detailed ground plan and elevation, Figure 3 and 4 , of the mill was due to his careful excavation of the lower parts of the mill channels where, in order to get the maximum benefit from the available drop in head, the water channels and the chambers containing the mill wheel axle supports had been constructed below ground level. These water passages and chambers below ground level had become filled with silt and debris soon after ville d'Arles et que la structure sur la pente face au sud de la crête étaient des vestiges d'un réservoir de clarification des eaux d'un type assez répandu dans les réseaux romains d'approvisionnement en eau. Ayant remarqué la différence entre les niveaux de lit des deux aqueducs, il ajouta que l'eau de l'aqueduc inférieur - celui qui passait par "le réservoir" - devait s'acheminer vers Arles indépendamment de l'autre sur une structure quelconque totalement disparue de nos jours. Un écrivain, contemporain de l'historien, qui avait examiné l'endroit attentivement pensait qu'il représentait un réservoir divisé en trois bassins majeurs et en un certain nombre de bassins mineurs et que ce lieu avait été le site de l'une des six manufactures impériales de tissu qui existaient à l'époque. Ce même écrivain remarqua des fragments de roue du moulin en basalte gisant au pied de la pente et il conclut que ces roues servaient à écraser le pigment coloré utilisé pour teindre les tissus. Un peu plus tard, un autre historien local identifia ces meules comme faisant partie d'un genre destiné à broyer le grain et conclut alors que ce lieu avait eu un double emploi - la finition des tissus et le broyage du grain, Un archéologue allemand qui écrivait sur les moulins de Nimes et d'Arles en 1910, accepta cette théorie de double fonction, mais pour $J$. Formige qui écrivait en 1924 [2], seule la minoterie y était pratiquée.

La fouille systématique du moulin était projetée dès 1935 puis réalisée en 1937 et 1938 par F. Benoit. Il fit paraitre un rapport complet [1] de ses recherches en 1940, par lequel il a définitivement conclu que la structure n'était pas un réservoir construit sur le flanc d'une colline, mais le corps de bâtiment d'un moulin conçu pour être actionné par des roues hydrauliques arrangées en deux cascades parallèles sur la pente descendante de chaque côté du batiment. Sa compétence à reconstituer un plan détaillé horizontal et en élévation (Fig. 3 et 4) du moulin fut le résultat du soin qu'il apporta à la fouille des parties inférieures des canaux du moulin. En effet, pour tirer le plus grand parti de la force de la chute, les canaux et les locaux contenant les supports de l'axe de la roue du moulin était construits sous terre. Ces canaux et locaux souterrains se remplirent 
the mill fell into disuse and this had not only preserved the masonry structure there in good order but it had also preserved the calcareous encrustations which were found to have formed on the water passage walls giving clear confirmation of their use and also by the manner in which these deposits had been formed and eroded suggesting ways in which the water wheels had been controlled by the deflection of water through openings in the mill chutes.

C.L. Sagui writing in 1948 [3] made estimates of the hydraulic power available at this site and also of the flour output. The two important quantities to be determined in arriving at the power availability are the head and the discharge. The total head across the mill can be measured today and is approximately $20 \mathrm{~m}$ but the discharge value is much more difficult to determine. Sagui measured the width of the approach acqueduct and found it to be $0.8 \mathrm{~m}$ (and this can be confirmed, see Fig. 7) but he also states that he saw deposits which suggested that the depth of flow in the aqueduct had been $0.5 \mathrm{~m}$. Today such marks are only visible in the Arles aqueduct where it appears that the depth of flow was nearer $1 \mathrm{~m}$. He then goes on to base his calculations on a discharge of $1 \mathrm{~m}^{3} / \mathrm{s}$ which implies that he is adopting a mean velocity of $2.5 \mathrm{~m} / \mathrm{s}$ in the mill aqueduct which is very high. The problem of water consumption will be discussed again later but it is sufficient to say here that the high discharge value adopted by Sagui leads to a power availability at each of the 16 water wheels which he believed would have been sufficient for each to drive two grindstones and his estimate of flour output is therefore based on 32 units. This he calculates to be 28 tonnes in 24 hours or enough to feed 80,000 people.

As well as the water consumption and flour output figures there remains another problem of interpretation in connection with the upper part of the mill site where the remains of two massive masonry walls set at an angle to the mill building enclose a triangular space between the termination of the aqueduct channel and the upper wall of the mill (see Fig. 3). These two inclined walls together with the missing upper end wall of the building have always been accepted as forming a distribution reservoir feeding the two mill channels but this interpretation is now in doubt as a stability analysis carried out for the missing third wall - the foundation bench cut in the rock is clearly visible and measurable - shows that is could not have retained water safely to the required depth.

The mill aqueduct : new estimates of discharge and flour production

Of the two aqueducts which cross the valley to the North of Barbegal (Fig. 5) the easterly one leading to the mill was supported for the most part on a continous masonry substructure or wall. The more westerly Arles aqueduct had a channel bed which ran at a higher level than that of its companion which made it more rapidement de vase et de débris dès que le moulin fut délaissé, ce qui eut pour effet non seulement de conserver cette partie de la maçonnerie en bon état, mais aussi les incrustations calcaires qui s'étaient formées sur les murs des passages d'eau et qui confirment donc clairement leur utilisation. La façon dont ces dépôts ont été formés et érodés suggère de quelle manière les roues hydrauliques ont été commandées par la déviation de l'eau à travers les ouvertures des chutes du moulin.

Dans ses écrits en 1948, [3] C.L. Sagui a donné des estimations de la force hydraulique fournie ainsi que du rendement en farine. Pour connaitre la force produite, deux facteurs sont importants : la hauteur de retenue et le débit. Il est toujours possible de mesurer la hauteur de chute totale, celle-ci est de $20 \mathrm{~m}$.; par contre, la valeur du débit est plus difficile à déterminer. Sagui a mesuré la largeur de l'aqueduc d'approche et a trouvé qu'elle était de $0,80 \mathrm{~m}$ (ceci peut être confirmé, voir Fig. 7), mais il a également spécifié qu'il a vu des dépôts qui laissent à penser que le niveau dans l'aqueduc était de 0,50 m. Ces traces ne sont visibles de nos jours que dans l'aqueduc d'Arles où il apparaitrait que le niveau était plutôt proche du mètre. A la suite de quoi il base ses calculs sur un débit de $1 \mathrm{~m}^{3} / \mathrm{s}$, ce qui implique qu'il adopte une vitesse moyenne de $2,5 \mathrm{~m} / \mathrm{s}$ dans l'aqueduc du moulin, ce qui est très élevé. Nous reviendrons plus loin sur les problemes de consommation d'eau et nous nous contenterons de dire ici que la valeur élevée du débit adoptée par Sagui donne à chacune des 16 roues hydrauliques une force suffisante, d'après lui, pour faire marcher 2 meules et ses estimations en farine produite sont donc basées sur le rendement de 32 unités. Ce rendement, d'après ses calculs est de 28 tonnes en $24 \mathrm{~h}$., c'est-à-dire une production suffisante pour nourrir 80.000 personnes.

De même que pour la consommation en eau et le rendement en farine, il existe un autre probleme d'interprétation se rapportant à la partie supérieure du site du moulin, là où les ruines des murs massifs en maçonnerie rattachés en angle au bâtiment du moulin entourent un espace triangulaire compris entre la terminaison du canal de l'aqueduc et le mur supérieur du moulin (voir Fig. 3). On a toujours pensé que ces deux murs inclinés, de même que la partie supérieure qui manque au mur de la construction, formaient un réservoir de distribution alimentant les deux canaux du moulin. Mais cette interprétation est maintenant mise en doute car une analyse de stabilité entreprise au sujet du troisième mur manquant - l'appui percé dans le rocher est clairement visible et peut être mesuré - montre que ce réservoir n'aurait pas pu retenir l'eau, sans risque, à la profondeur requise.

\section{L'aqueduc du moulin : nouvelles estimations du débit et de la production de farine}

Des deux aqueducs qui traversent la vallée au nord de Barbegal (Fig. 5), celui, à l'est, menant au moulin était supporté, sur la plus grande partie de son parcours, par une infrastructure continue en maçonnerie ou par un mur. Le lit du canal de l'aqueduc d'Arles, plus à l'ouest, avait un niveau plus élevé que son compagnon, 
economic to be constructed as a continuous arcade, a form commonly associated with Roman aqueducts although used in reality over a very small proportion of their total route length. It is thought that the Arles aqueduct was built first because the line of its companion can be seen (Fig. 2) to deflect strongly in a westerly direction at its junction with the mill enabling the mill to be orientated in the most advantageous direction on the slope of the hill.

Probably because the mill aqueduct was constructed on a solid substructure in the region close to the rock cutting, the "peiro troucado", much of this remains today. Enough in fact to make the measurement of aqueduct bed gradient a possibility. Figure 5 shows in plan the aqueduct remains in this region as they are today and it is quite easy to make out at gaps the precise upper level of the fine red concrete used here to line the aqueduct channel. Where it remains today this lining is covered by a thick calcareous deposit quite different in colour, texture and thickness from the concrete. This in its turn is covered by a layer of soil, stones and plants. Bed levels were determined at four stations along this part of the mill aqueduct where the upper surface of the lining material was accessible and ce qui rendait plus économique sa construction en arcade continue, forme classique dans les aqueducs romains, quoique utilisée en réalité sur une toute petite partie de la longueur totale de leur route. On pense que l'aqueduc d'Arles fut construit en premier parce que le tracé suivi par son compagnon parait dériver fortement vers l'ouest à son point de jonction avec le moulin (Fig. 2), permettant ainsi au moulin d'être orienté dans la direction la plus avantageuse sur la pente de la colline.

Il est probable que c'est parce que l'aqueduc du moulin a été construit sur une infrastructure solide dans la région près de la percée dans le rocher, le "peiro troucado", qu'une grande partie a subsisté jusqu'à nos jours. Suffisamment, en effet, pour qu'il soit possible de mesurer la pente du canal de l'aqueduc. La figure 5 montre en projection les vestiges de l'aqueduc dans cette région, tels qu'ils sont aujourd'hui, et, par les brèches on peut discemer facilement le niveau supérieur exact du ciment, fin et rouge, utilisé ici pour revêtir le canal de l'aqueduc. Là où subsistent encore des traces, le revêtement est couvert d'un épais dépôt calcaire de couleur, texture et épaisseur différentes de celles du ciment. Ce dépôt, à son tour, est recouvert d'une couche de terre, de pierres et de plantes. Les niveaux du lit ont

\begin{tabular}{|c|c|c|c|c|c|}
\hline \multicolumn{5}{|c|}{ Table 1. - Measurements of relative level and gradient for points on mill } \\
aqueduct bed as indicated in Figure 5 \\
Tableau 1. - Mesures du niveau relatif et de la pente en certains points du lit \\
de l'aqueduc indiqués sur la figure 5
\end{tabular}


also at one point on the bare rock surface. The position of the five level stations is indicated in both Figure 3 and 5 and the results in the table below:

In the table a positive gradient indicates a falling bed level in the assumed downstream flow direction. The results achieved are erratic which could be explained by a number of possibilities:

a) the aqueduct builders did not work to a very precise bed gradient and here it should be remembered that a short length of adverse gradient would not seriously affect the functioning ot the aqueduct;

b) parts of the aqueduct substructure built on alluvial material may have settled more than other parts, probably immediately after construction;

c) the whole area may have tilted to the north due to crustal deformation along the margin of the Mediterranean basin during the last 1700 years;

d) the level measurements may be in error.

The level traverses all closed within acceptable limits and were repeated a number of times so that (d) seems unlikely but it is possible that some of the measurements did not in fact lie on the original bed of the channel due to local damage or repair of the lining material. The substructure under station 1 is far enough away from the ridge to have suffered settlement but it is difficult to see why $3 \mathrm{~A}$ should have gone down when 2 did not. The possibility of a general tilting of the whole area can be resolved in the future if levels can be taken of the aqueduct bed at some point on the north side of the valley where the aqueduct is once more resting on bed-rock and these related to levels at station 3 . It is quite possible that one day these levels will be seen to have been affected by more than one of the above factors and maybe others as well.

It will now be seen that it is not possible at present to establish the discharge by first determining the aqueduct gradient. However, from experience with sewers of about the same dimensions, it would seem that a mean velocity of $1 \mathrm{~m} / \mathrm{s}$ is much more probable in this case than the $2.5 \mathrm{~m} / \mathrm{s}$ implied in Sagui's calculations. Another quite separate aspect of the discharge problem which should be considered is the discharge capacity of an overshot waterwheel of the dimensions used here. A wheel diameter of about $2.1 \mathrm{~m}$ fits in with the measurements of the mill channels and an effective (inner) wheel width of $0,7 \mathrm{~m}$ is the greatest that could be accommodated with safety in the stone channels $1 \mathrm{~m}$ wide. Assuming a speed of rotation of 10 r.p.m. and an equivalent uniform bucket depth of $0.2 \mathrm{~m}$ gives a usable discharge of $0.15 \mathrm{~m}^{3} / \mathrm{s}$ although the actual value may have been considerably less. This gives an aqueduct discharge of $0.3 \mathrm{~m}^{3} / \mathrm{s}$ which results in a mean velocity of $0.8 \mathrm{~m} / \mathrm{s}$ and a gradient (using a Manning $n$ value of 0.015 ) of 0.001 . été mesurés en quatre stations le long de la partie de l'aqueduc du moulin où la surface supérieure $d u$ matériau de revêtement était accessible de mème qu'en un point sur la surface dénudée du rocher. La position des cinq stations de niveau est indiquée sur les figures 3 et 5 et les résultats dans le tableau ci-dessous :

Dans le tableau, une pente positive indique un niveau de lit en baisse vers l'aval présumé. Les résultats obtenus sont erratiques et à cela il y a plusieurs explications possibles:

a) les constructeurs de l'aqueduc n'ont pas travaillé sur la base d'une pente précise du lit et on doit rappeler ici que, sur une courte distance, une pente contraire n'affecte pas sérieusement le fonctionnement de l'aqueduc;

b) les parties de l'infrastructure de l'aqueduc bâties sur des matériaux alluvionnaires se seraient tassées plus que les autres parties, probablement immédiatement après la construction;

c) toute cette région se serait inclinée vers le nord suite à une déformation de l'écorce terrestre le long du bassin méditerranéen pendant les dernières 1.700 années; d) les mesures de niveau peuvent être erronées.

Les translations de niveau ne varient que dans des limites acceptables et ont été répétées plusieurs fois. La solution (d) parait donc improbable, mais il est possible que certaines mesures n'aient pas été faites dans le lit original du canal à cause d'une détérioration locale ou d'une réparation du matériau du revêtement. L'infrastructure sous la station 1 est assez éloignée de la crête pour avoir été affectée par le tassement, mais il est difficile de comprendre pourquoi $3 \mathrm{~A}$ se serait tassée tandis que 2 restait inchangée. La possibilité d'une inclinaison générale de toute la région peut être vérifiée dans l'avenir si l'on peut mesurer les niveaux du lit de l'aqueduc en quelque point du côté nord de la vallée où l'aqueduc repose à nouveau sur de la roche et que ceux-ci soient comparés aux niveaux de la station 3. Il est fort possible qu'un jour on découvre que ces différents niveaux ont été affectés non pas seulement par l'un des facteurs déjà cités, mais par plusieurs d'entre eux à la fois et peut-être par d'autres également.

Nous allons voir qu'il n'est pas possible d'établir le débit en commençant par déterminer la pente de l'aqueduc. Cependant, en se basant sur l'expérience d'égouts de dimensions voisines, il semblerait qu'une vitesse moyenne de $1 \mathrm{~m} / \mathrm{s}$ est plus probable dans ce cas que celle de 2,5 $m$ adoptée dans les calculs de Sagui. Un autre aspect du problème de débit à considérer est la capacité du débit d'une roue hydraulique mue endessus et possédant les dimensions utilisées ici. Les dimensions des canaux du moulin conviennent à une roue d'un diamètre de $2,1 \mathrm{~m}$; or, 0,7 $\mathrm{m}$ est la plus grande largeur intérieure effective de roue pouvant se loger sans risque dans les canaux en pierre d'un mètre de large. Avec une vitesse de rotation de 10 tours/min et une profondeur d'auget équivalant $\grave{a}$ $0,2 \mathrm{~m}$, on a un débit utile de $0,15 \mathrm{~m}^{3} / \mathrm{s}$ bien que la valeur réelle ait pu être considérablement moindre. Ceci nous donne pour l'aqueduc un débit de $0,3 \mathrm{~m}^{3} / \mathrm{s}$ ce qui se traduit par une vitesse moyenne de $0,8 \mathrm{~m} / \mathrm{s}$ et une pente de 0,001 (en utilisant une valeur $n$ de Manning de 0,015). 
It now appears that the potential power available from this aqueduct was $60 \mathrm{~kW}$, not Sagui's value of $196 \mathrm{~kW}$ and, if his $65 \%$ efficiency is accepted, each waterwheel could now have generated $2 \mathrm{~kW}$ compared with the previous figure of $6.6 \mathrm{~kW}$. However, a millstone of $0.9 \mathrm{~m}$ diameter - the size suggested by the fragments found - has been estimated to need $3.6 \mathrm{~kW}$ at an assumed speed of 53 r.p.m. so that it now looks as though this speed of rotation may not have been realised here and the estimated output of milled flour must be reduced accordingly from 40 to $24 \mathrm{~kg}$ per hour per stone. It is also quite clear that there was never any possibility of each waterwheel powering two grindstones (as Sagui calculated) so the maximum flour production now stands at 9 tonnes per 24 hours continuous output for the whole mill.

Time lost due to the maintenance needs of the aqueduct and the mill machinery must have been large and in addition there must have been interruptions due to inadaquate supplies of grain or water as well as normal management and labour disruptions. It would therefore seem reasonable to assume a $50 \%$ load factor for the mill and this cuts its average flour production down to 4.5 tonnes per day or enough to feed a population of 12,500 based on a consumption unit of $350 \mathrm{~g}$ per day. This corresponds closely enough to estimates of the size of population of Arles in the fourth century $A D$ so that it would now appear that Sagui was incorrect in assuming a substantial export trade in milled grain from Arles at that period due to Barbegal alone.

\section{The mill and the water distribution arrangements}

Une of the more obvious features of the Barbegal site is that water was supplied by a single channel cut through the crest of the ridge, Figure 6 , at the upper end and was discharged by a double channel arrangement at the bottom. The arrangements at the lower end were made clear by Benoit's excavations and these still remain substantially open to inspection, Figure 8. It was by a process of backward extrapolation from these low chambers and water channels that Benoit was able to arrive at his reconstruction of the whole mill, Figure 3 and 4 . There is nothing in the remains today (Fig. 2) to contradict his scheme of a double eight-stage water mill arrangement with each waterwheel contained in its own step in the channel and each millstone assembly housed in the corresponding internal chamber in the mill building.

The mill structure can be considered as five longitudinal divisions. The two outer ones, shown in Figure 9 and 10 respectively, being essentially masonry walls $3.5 \mathrm{~m}$ thick, each containing a stepped mill water course. The two next to these consist of stepped rooms containing the mill machinery probably of several stories each, while the remaining central divisions consisted originally of an access passage including timber platforms and timber and masonry stairs. This permitted the movement of grain and flour between
Il semble maintenant établi que la puissance potentielle de cet aqueduc était de $60 \mathrm{~kW}$, et non de $197 \mathrm{~kW}$ comme l'avait évaluée Sagui et, si l'on admet un rendement de $65 \%$, chaque roue hydraulique aurait pu alors produire $2 \mathrm{~kW}$ au lieu du chiffre précédernment avancé de $6,6 \mathrm{~kW}$. Cependant, on a estimé que pour faire marcher une meule de $0,9 \mathrm{~m}$ de diamètre (diamètre déduit des fragments découverts), à la vitesse présumée de 53 tours $/ \mathrm{min}$, il fallait une puissance de $3,6 \mathrm{~kW}$. De sorte qu'il semble maintenant que cette vitesse de rotation n'ait pu être atteinte et l'on doit donc, en conséquence, réduire le débit de la mouture de 40 à $24 \mathrm{~kg}$ par heure et par meule. Il est aussi très clair qu'aucune de ces roues n'a pu faire tourner deux meules à la fois (comme l'avait avancé Sagui), de sorte que la production maximum de farine pour tout le moulin est maintenant estimée à 9 tonnes par 24 heures.

D'autre part, l'entretien du moulin et de l'aqueduc a dû occasionner de grandes pertes de temps et il faut tenir compte des interruptions probables provoquées par le manque de grain ou d'eau ainsi que par les problèmes habituels d'encadrement et de main-d'oeuvre. Il paraitrait alors plus raisonnable de tabler sur un facteur de charge de $50 \%$ pour le moulin, réduisant ainsi la production moyenne de farine à 4,5 tonnes par jours, de quoi nourrir une population de 12.500 personnes, à raison de $350 \mathrm{~g}$. par jour et par personne. Ceci se rapproche assez des estimations de la population d'Arles au $4^{e}$ siècle et, il semble donc que Sagui se trompait en émettant l'hypothèse qu'un important commerce d'exportation de grain moulu existait à cette époque-là à partir d'Arles, grâce au seul moulin de Barbegal.

\section{Dispositifs du moulin et de la distribution d'eau}

Une des caractéristiques les plus évidentes du site de Barbegal est le fait qu'il était alimenté en eau par un seul canal percé au sommet de la crête (Fig. 6), à son extrémité supérieure, et que l'écoulement se faisait en bas par le dispositif d'un double canal. Ce dispositif a été mis à jour par les fouilles de Benoit; il est encore visible aujourd'hui (Fig. 8). C'est en partant, en sens inverse, de l'installation du bas et des canaux que Benoit a pu arriver a reconstituer tout le moulin (Figures 3 et 4). Rien dans les vestiges d'aujourd'hui (Fig. 2) ne contredit son pland'un dispositif comprenant un moulin à eau et un double arrangement de 8 roues hydrauliques étagées; chaque roue étant logée dans son propre palier dans le canal et chaque meule et son ensemble dans une pièce interne du bâtiment proprement dit.

On peut considérer que la structure du moulin consiste en cinq sections longitudinales. Les deux de l'extérieur représentées en figures 9 et 10 respectivement, sont essentiellement des murs en maçonnerie d'une épaisseur de 3,5 m, chacun contenant un chenal en gradins. Les deux d'à côté consistent en chambres en gradins contenant le mécanisme du moulin et de plusieurs étages chacune. La division centrale se composait à l'origine d'un passage d'accès comprenant des plates-formes en bois et des marches en bois et 

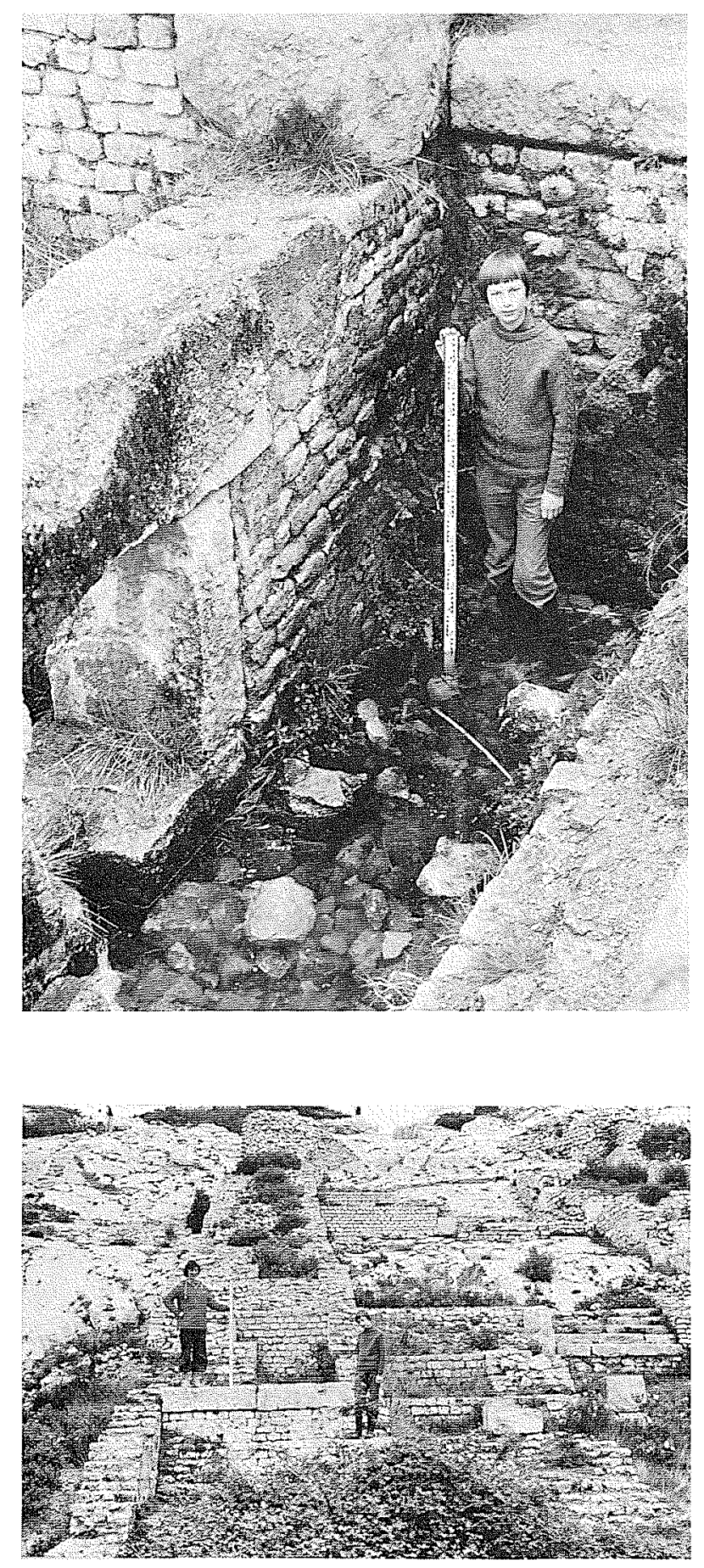

the entrance to the building (centre front) and the individual mill rooms. The lower courses of many of these internal walls are standing today, the plan being fairly complete on the E. side of the building and rather less so on the $\mathrm{W}$. A systematic arrangement in four rows of 14 large stones, or their foundation platforms, are thought to have supported a system of pillars which probably carried a timber and tile roof across the whole mill building. This may well have been stepped in elevation in line with the internal mill chamber arrangements as shown in Sagui's reconstruction of the mill, Figure 11. Whether the roof covered the
Figure 8 - Lowest waterwheel chamber (1) in eastern watercourse of mill.

Figure 8-La plus basse des chambres à roue hydraulique (1) sur la chute d'eau côté est.

Figure 9 - Western water channel structure. Figure 9 - La structure du canal côté ouest.

maçonnerie. Ce passage permettait le transport du grain et de la farine entre l'entrée du bâtiment (au centre à l'avant) et les chambres individuelles du moulin. Les parties inférieures d'un grand nombre de ces murs internes sont toujours debout, le plan en est assez détaillé sur le côté est du bâtiment, mais l'est moins sur le côté ouest. On pense que le dispositif systématique de 14 grandes pierres en quatre rangées ou leurs platesformes de fondation supportaient un système de piliers sur lequel reposait un toit en bois et tuiles qui couvrait tout le batiment du moulin. Il est possible que le tout ait été installé en gradins à l'image des pièces intérieures 
Figure 10 - Lowest three chambers of eastern water channel. Figure 10 - Les 3 chambres les plus basses sur le canal côté est.
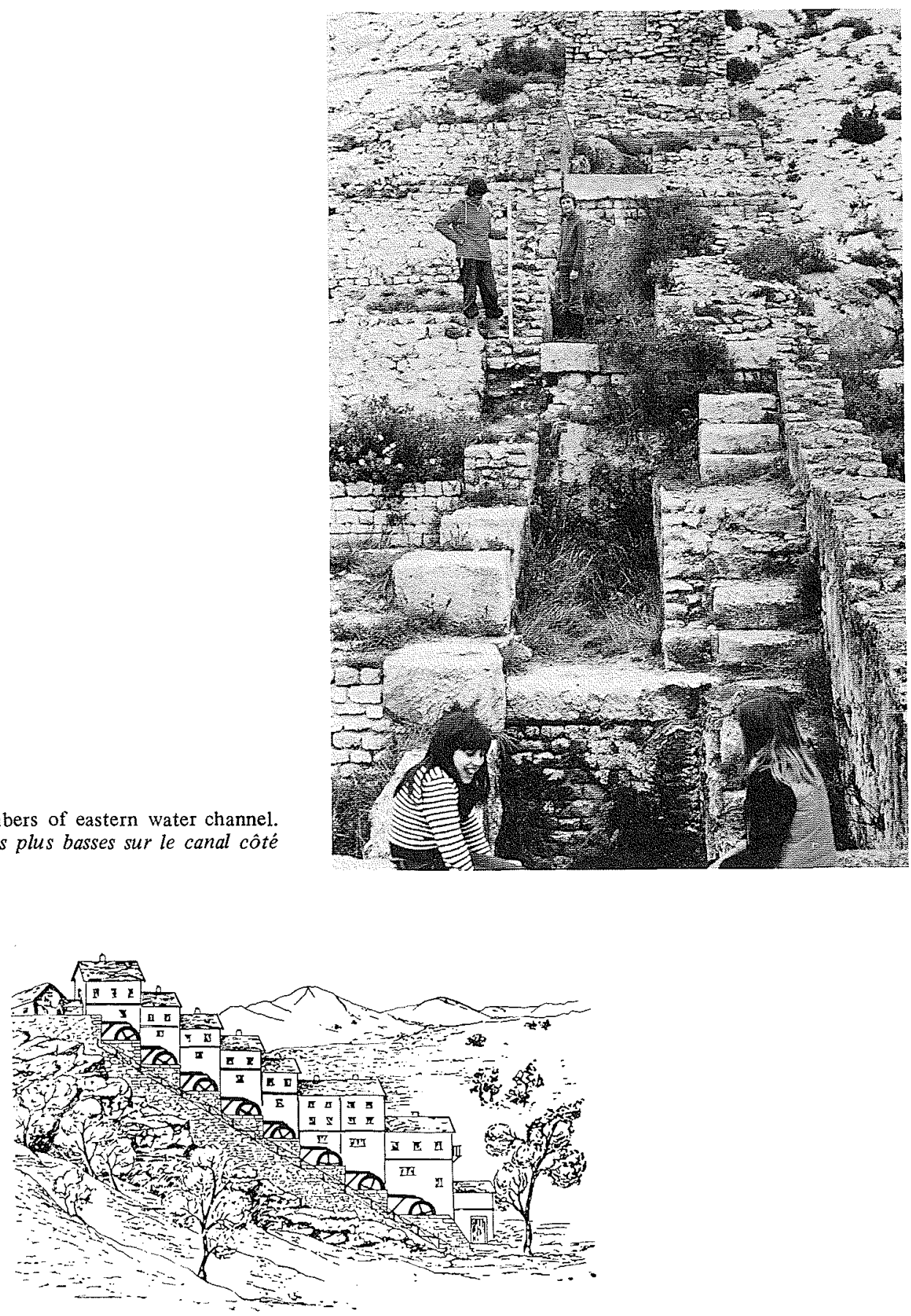

Figure 11 - Sagui's reconstruction of the mill at Barbegal.

Figure 11 - La reconstitution par Sagui du moulin de Barbegal.

three central divisions of the building in a single pitch or was constructed separately over the two mill chamber divisions with an auxiliary unpitched roof, following the slope of the hill, over the central access corridor cannot now be determined.

To judge from Figure 11 Sagui had experienced some difficulty with the roof, or had not appreciated the problem, because his drawing leaves the matter unresolved. One point is clear; he had access to Benoit's drawings when he prepared his own reconstruction. If Benoit's positioning of the 8 waterwheels is correct du moulin comme il est indiqué dans la reconstitution du moulin par Sagui (Fig. 11). On ne peut de nos jours déterminer si le toit couvrait les trois sections centrales du bâtiment d'un seul tenant ou si un toit recouvrait séparément les deux sections de pièces internes du moulin, avec un toit auxiliaire plat suivant la pente de la colline et couvrant le passage central d'accès.

$A$ en juger par la figure 11, Sagui a éprouvé quelques difficultés avec le toit ou a négligé le problème car son croquis in'apporte aucun éclaircissement. Une chose est claire : il a eu accès aux dessins de Benoit quant il a préparé sa propre reconstitution. Si la position donnée aux 8 roues hydrauliques par Benoit est exacte, (Fig. 4) 
(Fig. 4) there are some interesting points which arise and which he discusses in his report. A millstone must be mounted with its shaft vertical and a waterwheel of this type with its shaft horizontal. This means that a satisfactory right-angled gearing is required and that the millstones must either be on a floor above the waterwheel shaft or on a floor below. Looking at the profile and section in Figure 4 it seems most probable that the millstones in chambers 1.3 were mounted above their wheels and those in $4-8$ below. There are certainly small recesses constructed below the floor level in chambers 1.3 (on the far side of the shaft opening in Fig. 8) which would have housed the inboard waterwheel axle bearing, the millstone shaft lower bearing and the gearing. For chambers 4 and upwards this arrangement would have been reversed which explains why the floor of chamber 4 is without any such low level recess and why it is benched into the hillside to a greater extent than its neighbours. Sagui is probably correct then in assuming that the central part of the mill building would have risen to several stories although his drawing does not agree with the site, or with Benoit's elevation, in his positioning of the lower water wheels. The lowest ones (chamber 1) would certainly have been out of sight probably below ground level (Fig. 8).

The triangular space at the top of the site has always been assumed to have formed a distribution reservoir for the two mill channels. Of the three walls enclosing this space substantial parts of the two diagonally inclined ones remain (Fig. 12 and 13) indicating that these were at least 2.5 , thick. All that remains of the

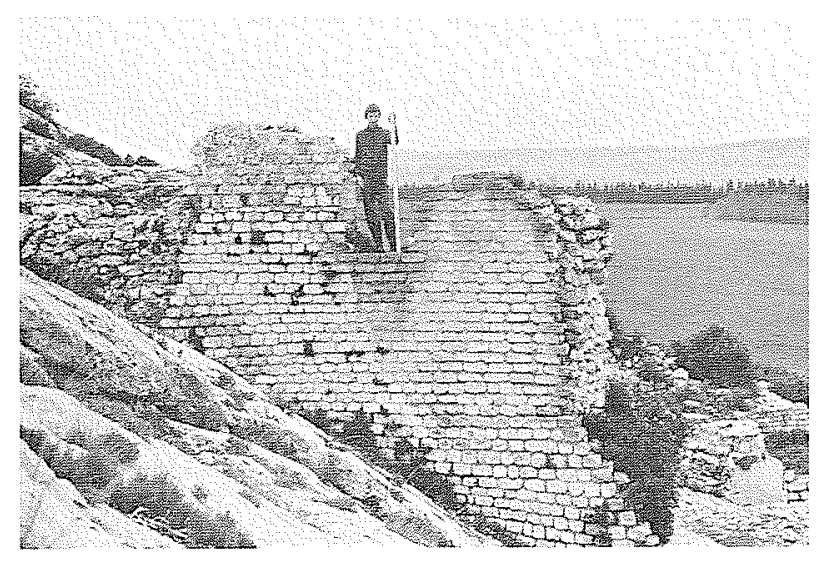

Figure 12 - Western diagonal wall at top of slope.

Figure 12 - Le mur diagonal, côté ouest, en haut de la pente.

third wall however, which also formed the upper end wall of the mill building, is a carefully cut and clearly visible foundation bench some $1.1 \mathrm{~m}$ wide shown in Figure 13 and running the full width of the building. If this space did in fact contain a distribution reservoir then the missing wall must have successfully withstood a hydrostatic pressure distribution on its uphill side quelques questions intéressantes se posent et elles sont traitées dans son rapport. Une meule doit être montée de telle façon que son arbre soit vertical et une roue hydraulique de ce genre avec son arbre à l'horizontale. $C e$ qui vent dire qu'un engrenage satisfaisant $\dot{a}$ angle droit est nécessaire et que la meule doit se trouver soit à l'étage au-dessus de l'arbre de la roue hydraulique soit à l'étage en dessous. D'après le profil et la section de la figure 4, il semble plus probable que les meules des chambre 1 à 3 étaient montées au-dessus de leurs roues et celles des chambre $4 \dot{a} 8$, en dessous. Il existe certainement de petits renfoncements construits en dessous $d u$ niveau du plancher dans les chambres 1 à 3 (sur le côté le plus éloigné de l'ouverture pour l'arbre de la figure 8) pour loger le palier de l'arbre de la roue hydraulique inférieure, le palier inférieur de l'arbre de la meule et l'engrenage. A partir de la chambre 4, ce dispositif aurait été inversé, ce qui explique pourquoi le plancher de la chambre 4 est dépourvu de renfoncement au sol et pourquoi il s'enfonce plus profondément dans la colline que ses voisins. Sagui a sans doute raison, alors, en supposant que la partie centrale du bâtiment du moulin était haute de plusieurs étages bien que son plan ne soit pas en accord avec le site ou avec la coupe de Benoit, dans son positionnement des roues hydrauliques inférieures. Les roues les plus basses (chambre 1) n'auraient certainement pas été visibles, se trouvant probablement sous terre (Fig. 8).

On a toujours pensé que l'espace triangulaire en haut du site formait un réservoir de distribution pour les deux canaux du moulin. Des trois murs entourant cet espace, il reste encore une assez bonne partie des deux murs inclinés diagonalement (Fig. 12 et 13) et l'on peut voir que ces murs avaient une épaisseur d'au moins $2,5 \mathrm{~m}$.

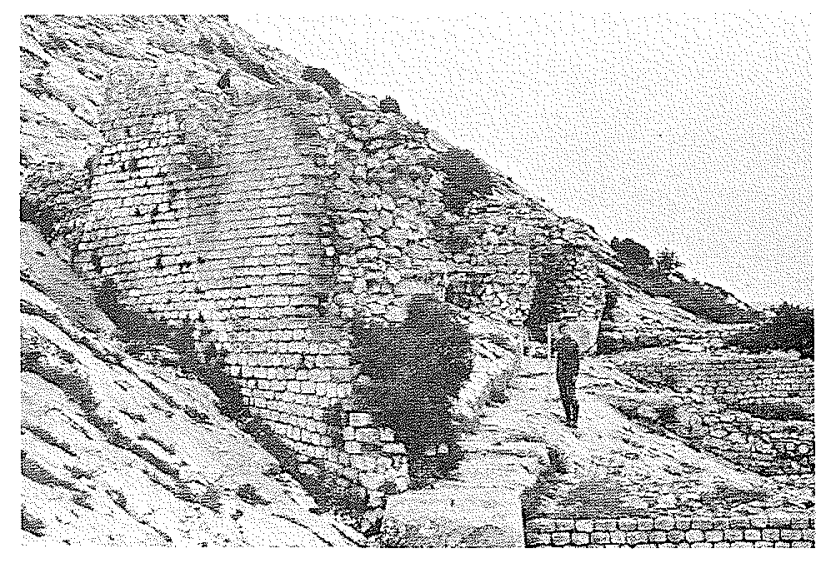

Figure 13 - Foundation bench for missing end (North) wall of mill building.

Figure 13-Appui du mur manquant à l'extrémité nord du bâtiment du moulin.

Du troisième mur, qui formait aussi la partie supérieure du mur situé à l'extrémité du moulin, il ne reste qu'un appui, soigneusement découpé et nettement visible, d'une largeur d'environ $1,1 \mathrm{~m}$; cet appui, que l'on voit sur la figure 13, longe le bâtiment sur toute sa largeur. Si cet espace contenait effectivement un réservoir de répartition, le mur manquant avait à supporter une pression 
corresponding to the level of the water surface in the reservoir relative to the base of the wall. Whether or not the reservoir bottom was formed on a horizontal platform constructed behind the end wall is not likely to have affected significantly the horizontal loading on this wall unless the reservoir was essentially watertight and the supporting structure, now vanished, very well drained. What can be easily demonstrated is that if this wall, with a base width not exceeding $1.1 \mathrm{~m}$, had been subjected to an upstream hydrostatic pressure distribution over its full height due to a water level equal to the inferred level of entry to the mill channels then its factor of safety against overtuming would have been 0.3 and against failure by sliding 0.85 . This situation would have been impossible. Even if a sufficiently shallow and watertight reservoir had been successfully constructed on an adequately drained base it seems very probable that at sometime during the useful lifetime of the mill (thought to have been 100 years) the drainage would have become blocked and again failure of the wall would have occured. This dangerous situation could easily have been avoided by providing a simple channel fork where the aqueduct leaves the rock cutting (the rock walls are in fact cut back at the correct angle for the last $2 \mathrm{~m}$ of the cutting) and running two separate channels out over the very substantial diverging walls still remaining and shown in Figure 12. This reconstruction of the water distribution arrangements avoids altogether the need for a reservoir and was first suggested by A.J. Parker [4]. It would appear to be supported strongly by the difference in thickness of the walls under consideration; $2.5 \mathrm{~m}$ for the diverging walls and $1.1 \mathrm{~m}$ for the foundation of the transverse wall. The only requirement that this scheme makes on the transverse wall in that there should have been some provision for drainage to prevent rain water and seepage from the aqueduct from accumulating in the enclosed space formed by the three walls.

A feature of the diverging walls which, perhaps more than any other single factor was taken to support the reservoir theory is the existence of an opening high up in each, see Figure 12, with their lower sills 1.4 and $0.7 \mathrm{~m}$ respectively below the present day levels of the tops of the walls. These were interpreted as drainage openings serving a reservoir with its bottom at the sill level and used from time to time to flush out silt. If this was so it is difficult to see why an opening was provided on each side as a single one would have served one reservoir well enough and made the provision of a drainage channel to carry the water from here to the foot of the slope and clear of the mill area much simpler.

There are clear signs of a boundary wall having enclosed the mill building and a surrounding ground area. The regular stepped foundation can be seen on the left of Figure 2 and the full plan has been drawn in by Benoit, Figure 3. This wall could have caused further problems if water had been released from these openings in large quantities. Alternatively, it is possible that they were part of a flow control or diversion hydrostatique sur son côté amont correspondant au niveau de la surface de l'eau dans le réservoir par rapport à la base du mur. Que le fond du réservoir ait reposé ou non sur une plate-forme horizontale construite derrière le mur d'extrémité, cela n'a probablement pas eu une grande incidence sur la charge horizontale supportée par ce mur, à moins que le réservoir ait été tout à fait étanche et la structure de soutien, maintenant disparue, très bien drainée. Ce que l'on peut démontrer très facilement est le fait que si ce mur, avec une largeur à la base n'excédant pas $1 \mathrm{~m}$, avait été soumis à une pression hydrostatique en amont sur toute sa hauteur du fait d'un niveau d'eau égal au niveau supposé $\grave{a}$ l'entrée des canaux du moulin, son facteur de sécurité, dans le cas d'une inversion, aurait été alors de 0,3 et dans le cas d'un éboulement de 0,85. Cette situation eut été impossible. Même si un réservoir suffisamment étanche et peu profond avait été bien construit sur une base convenablement drainée, il semble très probable qu'à un moment donné pendant la vie utile du moulin (estimée à environ 100 ans), le système de drainage se serait obstrué et là encore le mur se serait écroulé. Cette situation dangereuse aurait pu être évitée en prévoyant une bifurcation du canal à l'endroit où l'aqueduc quitte la percée dans le rocher (les murs du rocher sont en fait entaillés sous un angle correct sur les derniers 2 mètres de la percée) et en faisant partir les deux canaux séparés sur les deux grands murs divergents qui sont toujours là et représentés sur la figure 12. Cette reconstitution des systemes de distri: bution d'eau élimine complètement la nécessité d'un réservoir et fut suggérée pour la première fois par A.J. Parker [4]. Il apparaitrait que cette version est fortement corroborée par la différence d'épaisseur des murs en question : 2,5 m pour les murs divergents et $1,1 \mathrm{~m}$ pour la fondation du mur transversal. La seule condition que ce schéma impose au mur transversal est qu'on ait prévu un système de drainage afin d'éviter l'accumulation d'eau de pluie et le suintement de l'aqueduc dans cet espace clos fermé par les trois murs.

Une des caractéristiques de ces murs divergents qui, plus que tout autre facteur, a contribué à corroborer la théorie du réservoir, est l'existence d'une ouverture placée très haut sur chaque mur (voir Fig. 12), dont les seuils inférieurs se trouvent respectivement $\grave{a} 1,4$ et $0,7 \mathrm{~m}$ du niveau supérieur actuel des murs. On a supposé que ces ouvertures servaient au drainage d'un réservoir dont le fond était au niveau du seuil et qu'elles étaient utilisées, de temps en temps, pour évacuer les dépôts. S'il en était ainsi, on a du mal à comprendre pourquoi il $y$ avait une ouverture de chaque côté, quand une seule eût suffi pour un réservoir et eît simplifié l'installation d'un système de drainage pour évacuer l'eau jusqu'au pied de la pente et loin du moulin.

Il existe des indices très nets d'un mur de délimitation qui aurait entouré le moulin et le terrain avoisinant. La fondation, en gradins réguliers, est visible à gauche de la figure 2 et le plan complet a été dessiné par Benoit (Fig. 3). Ce mur aurait pu être la source d'autres problèmes si l'eau avait été évacuée par ces ouvertures en grande quantité.

Il est également possible qu'elles aient fait partie 
structure in the twin channels that it is suggested ran along the top of these diverging walls. Finally, on this point, it is not clear what purpose a distribution reservoir could have served at this location. Its water storage capacity would have been insignificant and if a settlement tank had been required to trap sediment carried by the water an appropriate structure could have been provided much more easily further back along the aqueduct.

The Gallo-roman mill at Barbegal has clearly been of great interest to local historians and archaeologists particularly in relation to the economic and industrial organisation of the late Roman empire and it can also prove to be of interest to hydraulic engineers concerned with the early history of man's control over water and its useful application. This site must be one of very few constructed and operated and fallen into ruin before the industrial revolution in the West on which it is possible to make numerical estimates of discharges, power availability and output which help to put it and other early engineering works into context today. d'une structure pour le contrôle du débit ou de la derivation dans les canaux jumelés qui aurait longé le sommet de ces murs divergents. En ce qui concerne ce point, le rôle d'un réservoir de distribution à cet endroit n'apparait pas clairement. Sa capacité d'accumulation en eau aurait été insignifiante et si un réservoir de décantation avait été nécessaire pour arrêter les sédiments transportés par l'eau, une structure appropriée aurait pu être construite plus facilement, plus haut, sur l'aqueduc.

Le moulin gallo-romain de Barbegal est évidemment d'un grand intérêt pour les historiens locaux et les archéologues, particulièrement en ce qui concerne l'organisation économique et industrielle dans la dernière phase de l'empire romain. Il peut également éveiller l'intérêt d'ingénieurs hydrauliciens en ce qui concerne l'histoire des premiers efforts de l'homme pour la maitrise de l'eau et son utilisation pratique. Ce site doit être l'un des rares qui ont été construits, ont fonctionné et sont tombés en ruines avant la révolution industrielle en Occident, sur lequel on peut faire des estimations numériques quant au débit, à l'énergie produite et au rendement, ce qui aide à le situer, aussi que les autres premières réalisations du génie civil, dans le contexte actuel.

\section{References - Références}

[1] BENOIT F. - L'usine de meunerie hydraulique de Barbegal (Arles). Revue Archéologique, Série 6, 1940, 15, (1), pp. 19-80.

[2] FORMIGE J. - Les monuments romains de la Provence, Paris, Champion, 1924, p. 18.

[3] SAGUI C.L. - La meunerie de Barbegal (France) et les roues hydrauliques chez les anciens et au moyen âge, Isis, Feb. 1948,38 , pp. 225-231.

[4] PARKER A.J. - University of Bristol. Private communication. 